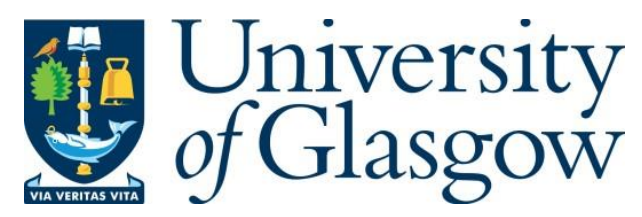

Mackillop, A. (2017) Riots and reform: burgh authority, the languages of civic reform and the Aberdeen riot of 1785. Urban History, 44(3), pp. 402-423.

There may be differences between this version and the published version. You are advised to consult the publisher's version if you wish to cite from it.

http://eprints.gla.ac.uk/149758/

Deposited on: 13 October 2017

Enlighten - Research publications by members of the University of Glasgow http://eprints.gla.ac.uk 


\title{
Riots and Reform: Burgh authority, the languages of civic reform, and the Aberdeen riot of 1785 1
}

\author{
ANDREW MACKILLOP \\ Department of History, University of Aberdeen, Old Aberdeen, AB24 3FX, UK
}

\begin{abstract}
This article explores the understudied riots which occurred in Aberdeen in midOctober 1785. It charts the climate of politicization that characterised the burgh's civic life in the immediate aftermath of the American Revolution and before the outbreak of the equivalent process in France. In doing so it challenges interpretations of the socially exclusive nature of the Scottish reform movement, the dynamics of continuity and change between this phenomenon and later political 'radicalism', and the role of Aberdeen as a 'provincial' metropolis in the Age of Revolution.
\end{abstract}

On 27 October 1785 the London-based Whitehall Evening Post, reported:

... accounts of the greatest discontents, which have shewn themselves for some years in Scotland, having broke out into acts of public outrage at Aberdeen. ... [P] risoners liberated by force; the Council Chamber was nearly destroyed, and the Magistrates obliged to fly for safety. The military were called in, but being found too few to counter the vast numbers of the disaffected, no use was made of them. ... They [the crowd] are supposed to be encouraged and stimulated by the Jacobite and Republican parties, who are both numerous in Aberdeenshire. ${ }^{2}$

In such terms did British metropolitan society, itself no stranger to large-scale, violent crowd activity, report on one of the United Kingdom's most northerly provincial metropoles. ${ }^{3}$ The portrayal of Aberdeen is a stark and in many ways a surprising one. Here apparently was a city riven with political ideologies from two different historical ages; the world of old-style Jacobite conservatism face-to-face with a republican spirit that might easily be mistaken for a direct manifestation of the new era of enlightenment and revolution. It is highly unlikely that contemporary opinion in London, Aberdeen or elsewhere understood 'Jacobite' and 'Republican' in quite this way. For most, the labels would have called to mind the constitutional experimentation and turmoil of the 1640s and 1650s and the widespread association of the north of Scotland with unconstitutional adherence to the Stuarts. But the quote also spoke of recent forms of discontent. The fact that older, historic divisions could be linked, however obliquely, with contemporary conditions is a telling indication of the substantial changes reshaping urban, civic and national political culture in Scotland four years before the outbreak of revolution in France.

\footnotetext{
${ }^{1}$ The author expresses his appreciation to the Tailors, Weavers, and Wrights and Coopers of the Incorporated Trades of Aberdeen for facilitating access to their archives and, additionally, for separate permission to consult the records of the Deacon Convenor's Court. In particular to: Ex-Deacon Convener Graeme Nicol (Ex-Deacon of the Weaver Incorporation); Deacon Convener David Parkinson (Ex-Deacon of the Tailor Incorporation); Deacon Graeme Thomson (Current Deacon of the Wrights \& Coopers); Deacon Ian T. Webster (Current Deacon of the Tailors); Deacon David Henderson (Current Deacon of the Weavers). All periods of office refer to 2014. ${ }^{2}$ White Hall Evening Post, 25 Oct. to 27 Oct. 1785 [No. 6000], 3. For reports of the riot in the Scottish press, see: The Aberdeen Journal, 24 Oct. 1785; The Scots Magazine, 47 (Edinburgh, 1785), 514.

${ }^{3}$ George F. E. Rudé, 'The Gordon Riots: a study of the rioters and their victims', Transactions of the Royal Historical Society (Fifth Series), 6 (1956), 93-114; Robert Shoemaker, The London Mob: Violence and Disorder in Eighteenth-Century England (London, 2004), 111-152.
} 
Dubiety over the precise nature of the ideologies at work in Aberdeen aside, the image of a divided city is striking. It offers a significant challenge to historiographical orthodoxies regarding the nature of eighteenth-century Aberdeen's civic society and the evolution of the town's political culture and rhetorical formulations. The early modern burgh has been pigeonholed as an innately conservative city, located in that most enduring of Scottish regional stereotypes, the conservative north east. ${ }^{4}$ This is despite the fact that during the 1770s and 1780s Aberdeen town and county exhibited clear reformist inclinations. ${ }^{5}$ That a track record in reform did not automatically produce later support for more radical objectives is a feature of the era's politics already identified for some of the major English towns. Birmingham, for example, hosted a vibrant reform culture before 1792 but experienced only limited and inconsistent engagement with radical activity thereafter. ${ }^{6}$ Despite the existence of a growing number of case studies of radicalism in individual Scottish urban centres, there is still some way to go in terms of fully understanding how this inconsistent dynamic between the two political ideologies operated in the Scottish towns of the period. ${ }^{7}$

A comprehensive grasp of what happened in Aberdeen before, during and after the riots of October 1785 can contribute in other ways to the historiographical reassessment of 'reform' and' radicalism'. Both concepts have been the subject of major reconsideration. Rather than an emphasis on existing as concrete, consistent phenomena, analysis has shifted to their inherently changeable, fluid natures and the mutually influencing effects each political trend had on the other. ${ }^{8}$ Then there is the particular interest in how these two different but overlapping ideologies originated and evolved in Scotland. A central concern in this respect has been the effort to establish whether Scottish political culture developed a deep rooted and innovative 'reform' movement and, if so, when? ${ }^{9}$ This question is closely tied to debates over whether reformist agendas facilitated the subsequent emergence of broadly populist and radical forms of politicisation and, if not, why not? ${ }^{10}$ There are sociological and geographical aspects to these issues. The extent to which respectable reform associations sought out or avoided alliances with trades and artisanal groupings within the major Scottish cities and towns is widely recognised as a topic in need of much greater research and analysis. ${ }^{11}$ In this context Aberdeen's comprehensive set of burgh council registers, when related to the minute books of the seven incorporated trades and the publications of reformminded burgesses, offer a major opportunity to explore if and how 'middling' reformers interacted with artisan interests, and with what consequences.

Then there is the matter of locating the spread of these political ideas and the role of the burgh's political, legal and civic infrastructure, including its hierarchy of municipal and

\footnotetext{
${ }^{4}$ For an influential statement on the idea of a 'conservative' north of Scotland, see G. Donaldson, 'Scotland's conservative north in the sixteenth and seventeenth centuries', Transactions of the Royal Historical Society, 5th ser. 16 (1966), 65-79. For its application in the eighteenth century see, David Allan, Scotland in the Eighteenth Century (London, 2002), 140.

5 James Vance, 'Constitutional radicalism in Scotland and Ireland in the era of the American Revolution,' Unpublished Ph.D, (University of Aberdeen, 1998), 316.

${ }^{6}$ Bob Harris, The Scottish People and the French Revolution (London, 2008), 13 \& 83.

${ }^{7}$ Bob Harris, 'How radical a town? Dundee and the French Revolution', in Charles McKean, Bob Harris, and Christopher A. Whatley (eds.) Dundee: Renaissance to Enlightenment, (Dundee, 2009), 186.

${ }^{8}$ Mark Philp, 'The fragmented ideology of reform', in Mark Philp (ed.), The French Revolution and British Popular Politics, (Cambridge, 1991), 53-6.

${ }^{9}$ Harris, The Scottish People, pp. 13-19; Gordon Pentland, 'The challenge of radicalism to 1832', in The Oxford Handbook of Modern Scottish History, eds. T.M. Devine and Jenny Wormald (Oxford, 2012), 440-441.

${ }^{10}$ Henry W. Meikle, Scotland and the French Revolution (Glasgow, 1912), 1-40; John Brims, 'From reformers to "Jacobins": The Scottish Association of the Friends of the People', and Stana Nenadic, 'Political reform and the 'ordering' of middle-class protest', in T.M. Devine (ed.) Conflict and Stability in Scottish Society, 1700-1850 (Edinburgh, 1990), 31-35, 66-7.

${ }^{11}$ Harris, The Scottish People, 17-18, 38-40.
} 
artisanal courts, in the process of such dispersal. It remains unclear whether developments in a regional metropole like Aberdeen relied largely upon internal dynamics or evolved mainly in response to external stimuli, be these events in North America, France and Ireland or new forms of popular politics and print media emanating in the main from the national metropoles of Edinburgh and London. In this sense what occurred in Aberdeen in 1785 can cast revealing light on much broader debates. As the 'Age of Revolutions' has been redefined within wider global trends, there is a new emphasis on the ways in which ideas and practices infused with universalist, 'natural law' connotations interacted with often highly localised conditions and priorities. ${ }^{12}$ A key point of consensus among these various revisions is the need for far greater contextualisation and sensitivity to national, regional and local circumstances, and a more consistent awareness of the inherently heterogeneous, dynamic and malleable nature of politics at this time. ${ }^{13}$ Recapturing Aberdeen's political culture during the year between c. 1775 and c. 1795 - the midpoint of which witnessed one of the most dramatic examples of popular tumult in the town's early modern history - can be one such contextually-grounded case study.

\section{Cultures of urban reform: the case of later eighteenth-century Aberdeen}

A useful starting point is to avoid the teleology implied in 'reform' politics setting the stage for the later emergence of 'radical' ideology. This whiggish formulation risks viewing one phenomenon as a weak, innately conservative forerunner of the latter, and treats neither on their own terms. The last quarter of the eighteenth century is better viewed, at least as far as conditions in Aberdeen are concerned, less as one of clearly defined sequential phases of 'reform' and 'radicalism' but as an era marked by the evolution of a vibrant, multilayered, overlapping and unpredictable civic politics. If overall trends in the burgh pointed clearly towards a quickening of political tempo during the years surrounding the riot, this did not happen in a steady, one-directional way. International developments like the war against the Americans, national controversies such as proposed relief for Catholics, or purely local events such as the Michaelmas head courts produced an irruptive, stop-start dynamic. The city's political scene in the years before and after the 1785 riots exhibited phases of intense controversy followed suddenly by periods of calm, consensus, and even inertia.

Never the less the cumulative effect is clear. Issues of municipal authority and legal precedent ensured that the role of burgesses, incorporated tradesmen and, in some strictly limited and ambiguous ways, the general inhabitants in constituting the burgh community were intensely debated, contested and redefined. Concepts of how the town was ordered and what its archival records and popular customs said about those who had the right to be involved in its governance came under unprecedented scrutiny and debate. As a result, the council and the officially recognised trade incorporations experienced a tense climate of strain, dispute and division, both in relation to each other and internally. On occasion the sense of heightened expectations and political posturing spilled over into polite new civic spaces like the assembly rooms on Queen Street, established sites such as the Tollbooth, and eventually onto the streets. ${ }^{14}$ Matters reached such a pitch that even Aberdeen's own

\footnotetext{
${ }^{12}$ David Armitage and Sanjay Subrahmanyam, 'Introduction: the age of revolutions, c.1760-1840 - global causation, connection, and comparison', in David Armitage and Sanjay Subrahmanyam (eds.), The Age of Revolutions in Global Context, c.1760-1840 (Basingstoke, 2010), xii-xvi.

${ }^{13}$ Gordon Pentland, 'Patriotism, universalism and the Scottish conventions, 1792-1794', History 89 (2004), 341, 358-61; Harris, The Scottish People, 6-7.

${ }^{14}$ The geography of Aberdeen at the time of the riot is captured in a contemporaneous map by Alexander Milne. N[ational] L[ibrary] of S[cotland], EMS.b.2.41, 'A plan of the City of Aberdeen with all the inclosures surrounding the town to the adjacent country, from a survey taken 1789 .'
} 
historical burgh records, a source of genuine local pride for what their ancient and unbroken nature said about the city's place in Scotland's urban hierarchy, became the subject of bitter controversy and exacting scrutiny. ${ }^{15}$ It is important to note the central role of the town's various courts in this increasingly fluid political climate. Courts were of course legal forums, constituted by formal, often royal, authority and a wide range of responsibilities which stretched beyond the purely judicial into areas of social regulation and the symbolic confirmation of the existing civic order. Yet they were also highly political. A key feature of ancien regime urban Scotland involved courts functioning as both the arbiters of, and platforms for, electoral politics. They were not just places of legal contest, justice and judgement; they were also where much of the political debate and voting took place in Scotland's towns. The need to see the burgh courts as sites of election and enfranchisement is at its most obvious in the ritualised annual selection of the new council in the aftermath of the Michaelmas head courts. Likewise, the convenors of each of Aberdeen's seven incorporated artisan guilds were elected at the 'Courts' of each of the individual trades. ${ }^{16}$

Yet if the urban courts offered an established platform for politics and electoral activity, it is clear they faced increasing competition. The patterns of intensifying and diversifying city politics that so marked out Aberdeen in the 1770s and 1780s formed part of the wider climate of 'discontent' in Scotland reported by the Whitehall Evening Post. The understudied riots of 17 and 18 October 1785 in Aberdeen were only the most dramatic manifestation of a wider and historically significant process of politicisation affecting the city. The results were erratic and sometimes directly contradictory but were recognised by contemporary observers across the rest of the United Kingdom as confirming Aberdeen's place as a leading centre of reformist endeavour in Scotland. ${ }^{17}$

If the prominence of the city's engagement with reform was noted by contemporaries, be it in the London press, pamphlets on Scottish political issues or the Wyvill reform association, this has not always been reflected in the subsequent historiography. In his ground breaking study of Scottish popular protest Logue stressed the Aberdeen riot's obscure origins and argued that traditional guild dynamics, more specifically tensions between freemen and journeymen and apprentices, most likely lay at the heart of the problem. This explanation was qualified by the suggestion that the outbreak might have been an attempt by the deacons of the incorporated trades as an employer's interest to smash the nascent collective organisation of their apprentices and journeymen. To Logue, the riots in 1785 were a proto-industrial dispute albeit one inflected with older assumptions about social hierarchy and privilege. ${ }^{18}$

By contrast, the most detailed survey of Aberdeen politics in this period omits consideration of the riot altogether, instead concentrating on the noticeably high-profile role of the city's burgesses in supporting national proposals for reform of Scotland's parliamentary and burgh electoral systems. The creation in early 1783 of 'The Committee of Burgesses of Aberdeen for a Reform in the Election of Magistrates' certainly heralded a

\footnotetext{
${ }^{15}$ Aberdonian authors took an obvious, often highly knowledgeable, pride in the city's complete and 'ancient' records. Alexander Skene, A Succinct Survey of the Famous City of Aberdeen (Aberdeen, 1685), 219, 223, 237; The Statistical Accounts of Scotland: http://stat-acc-scot.edina.ac.uk/link/1791-99/Aberdeen/Aberdeen/19/164/ [Accessed 04/8/2016].

${ }^{16}$ A[berdeen] C[ity] and A[berdeenshire] A[rchive], C1/1/65: Council Register from 17 Sept. 1782 to 10 May 1788, fos. 55, 65-67; Incorporated Trades of Aberdeen, T[rinity] H[all], The Convenor Court Book, vol. 2, 1764-1829: 10 Mar. 1789,

${ }^{17}$ Richard Warren, Speculum ruris, urbis and aulae: or, The Looking-glass, representing to town, court and country, the much need for reform (Edinburgh?, 1785), 331; Letters to the Citizens of Aberdeen; Attempting as a commentary on the letters of Oliver and other publications of that gentleman (Aberdeen, 1786), 5; Robert Graham, A Letter to the Right Honourable William Pitt, Chancellor of the Exchequer, on the reform of the internal government of the Royal Boroughs of Scotland (London, 1788), 42 \& 46.

${ }^{18}$ Kenneth J. Logue, Popular Disturbances in Scotland, 1780-1815 (Edinburgh, 1979), 162-64.
} 
major realignment of civic interests and underscores the northern burgh's capacity for early and conspicuous involvement in politically innovative tactics. ${ }^{19}$ The rhetoric and activities of this committee clearly presaged trends usually associated with the early 1790s. It organised general meetings which attracted over 200 burgesses, published pamphlets, sent letters to the Aberdeen Journal and made publically available petitions which the town's inhabitants were then invited to sign as a mean of demonstrating a wide base of popular support. ${ }^{20} \mathrm{Such}$ methods smacked of the tactics later deployed by the Scottish Association of the Friends of the People and other reform-inclined societies. ${ }^{21}$ The case for substantive continuities between the reform era in Scotland and innovative trends in the aftermath of revolution in France begins to look distinctly stronger when the activities, ambition, and political lexicon of the Aberdeen committee are considered in detail. It empowered ordinary burgesses and generated new but destabilising political connections with the incorporated trades. Finlay and Murdoch rightly surmise that the committee "was one of the most active in Scotland and, in some cases, the most successful'.$^{22}$ But no analysis as yet integrates the riot into this political context beyond a brief comment on the fact that in July 1786 the council alluded cryptically to opposition elements within the town defending rioters. ${ }^{23}$ Aside from this solitary hint no direct connection is made between the severe unrest in October 1785 and broader political trends.

The omission is entirely understandable when considering how the event was recorded. It is an indication of the collective sense of civic embarrassment that neither the burgh's council registers nor the minute books of the weavers, the tailors, the wrights and coopers and deacon convenor's court make any mention whatsoever of the disorder. The only way in which the council acknowledged the riot in its own recorded proceedings was an ordinance of 28 July 1786 prohibiting 'illegal and tumultuous meetings and processions' by apprentices and journeymen. ${ }^{24}$ The ruling magistrates deferred their response until after the trial of suspects and the climate of division and confrontation had cooled. The riots did receive detailed consideration in the Aberdeen Journal, other organs of the Scottish and British press and by justiciary court officials as they prepared the crown's case. But given the scale of the event - one of the most dramatic in the town's eighteenth-century history - the silence in the council and trades' records is deafening. The example of the riot raises intriguing methodological issues about what is recorded in Aberdeen's famously complete burgh records, and, crucially, what is not, and why.

\section{The Incorporated Trades and the riots of $17 \& 18$ October 1785}

The two days of rioting commenced on the afternoon of 17 October in the Schoolhill district in what was then the north-west limit of the burgh. The initial phase of disorder centred upon the wrights and coopers, one of the seven incorporated trades. Having just attended the annual election of their deacon and boxmaster (treasurer) at Trinity Hall, a procession of wrights apprentices and journeymen, carrying their flag and beating a drum, suffered an attack by cooper apprentices and journeymen; in other words, by members of

\footnotetext{
${ }^{19}$ The Aberdeen Almanack, for the year 1785 (Aberdeen, 1785), 189; Further Proceedings of the Burgesses of Aberdeen, in the years 1785, 1786, and 1787 (Aberdeen, 1787), iv-X.

${ }^{20}$ The Aberdeen Journal, 26 September 1785; 3 October 1785; 13 Feb. 1786

${ }^{21}$ Nenadic, 'Political reform', 69.

${ }^{22}$ David Finlay and Alexander Murdoch, 'Revolution to reform: eighteenth-century politics, c. 1690-1800', in E. Patricia Dennison, David Ditchburn and Michael Lynch (eds), Aberdeen before 1800: A New History, (East Linton, 2002), 281.

${ }^{23}$ Ibid, 282.

${ }^{24}$ ACAA, C1/1/65, fo. 140 .
} 
their own guild. ${ }^{25}$ Those orchestrating the internecine events were not formally constituted officeholders. In order to fully understand the origins of the riot, the way the less privileged members of the trades organised themselves must be fully understood. In a telling example of how the trades' corporate culture inculcated apprentices and journeymen with the principles and practice of court-based elections and a sense of indirect participation in financial decision-making, each of the artisanal societies evolved a custom of holding ballots for what were known as 'nominal' deacons and boxmasters. These strictly unofficial positions mirrored the formal hierarchy of trades' officers. The precise nature of the election, the status, authority and function of these 'nominal' post-holders remains unclear. In testimony collected at Aberdeen on 7 December 1785, a journeyman-wright, George Pirie, detailed their character and purpose. He noted how the servants of the different crafts 'have been in use in imitation of their masters to hold meetings and elect nominal deacon boxmasters and master of hospital', and, significantly, that this custom entailed each trade keeping a sederunt of participants. $^{26}$

The purpose of electing 'nominal' deacons and boxmasters seems to have been to ensure quasi-recognised representation for time-serving members of the incorporated trades who had yet to acquire full 'freeman' status. A particular concern among apprentices and journeymen involved the right to lobby on the matter of fees and their subsequent use. These customary elections followed the established burgh calendar, with 'nominal' officers chosen on the same day as their official counterparts. This co-option of formal dates and occasions imparted a reflected legitimacy to the proceedings. In this way a parallel electoral culture, if not legally sanctioned enfranchisement, extended down the social order to encompass elements of the town's population far removed from the level of formally constituted municipal or national affairs. The fact these elections occurred regularly and seem to have been tacitly accepted by the official deacons has major implications for assessments of the extent and character of pre-reformed Scottish burghal politics. Interpretations which stress the excessively narrow and oligarchic nature of urban governance remain valid, but are in need of qualification. ${ }^{27}$ Patterns of participation and expectations of who had some say, however marginal, in issues of nomination, election, office-holding and financial affairs encompassed a broader social spectrum than is usually recognised.

The immediate trouble sprang from this murky echelon of Aberdeen's social hierarchy. The initial outbreak on 17 October centred upon the procession led by the newly elected 'nominal' deacon of the wrights, a journeyman named Thomas Morice. Once this attack subsided, some journeymen wrights retired to a private household to consider the nature of their retaliation. The following morning a crowd of 40 to 50 journeymen and apprentice wrights and individuals from other trades, all led by Morice carrying a sword, gathered at the head of Shiprow and proceeded to the house of the locally prominent wright, John Lamb, who the day before had completed his term as official deacon of the wrights and coopers. At Lamb's house on the Netherkirkgate they acquired their trades' flag, a symbolic appropriation of legitimacy that seems to have particularly aggravated the situation. A series of street brawls followed as the protagonists moved through the main thoroughfares

\footnotetext{
${ }^{25} \mathrm{~N}$ [ational] R[ecords] of S[cotland], Edinburgh, High Court of Justiciary processes main series, JC26/242, 'Criminal Letters HM's Advocate agst Thomas Morice and others, Aberdeen, Spring 1786', Mob and Riot'. 18 Oct. 1785, Provost Cruden and Baillies Black, Paul and Copland. Testimony of Thomas Morice,

${ }^{26}$ NRS, JC26/242, 'Criminal Letters HM's Advocate agst Thomas Morice and others, Aberdeen, Spring 1786', 'Mob and Riot'. Aberdeen, 7 Dec. 1785: Testimony of George Pirie, journeyman wright, servant of John Smith, wright.

${ }^{27}$ T.M. Devine, 'The failure of radical reform in Scotland in the late eighteenth century: the social and economic context', in Conflict and Stability, 52; Bruce P. Lenman, 'From the Union of 1707 to the franchise reform of 1832', R.A. Huston and W.W.J. Knox (eds), The New Penguin History of Scotland From the Earliest Times to the Present Day (London, 2001), 323-324.
} 
threatening or attacking any cooper they met, all the while generating an ever larger crowd of new participants and spectators. Intervention by the authorities finally came as the throng moved up Marischal Street towards the Castlegate, Aberdeen's central civic space. It was at this moment that Lord Provost William Cruden and Lamb's replacement as deacon of the wrights and coopers, a cooper named William Still, remonstrated with those assembled and attempted to seize the flag. The crowd repeatedly ignored the pleas of men who ought to have commanded obedience on the grounds of occupational loyalties and civic deference. During all these proceedings a small detachment of soldiers shadowed the crowd and eventually succeeded in arresting Morice and two others. ${ }^{28}$

As the autumn afternoon turned to evening and darkness fell, the scenes described in the Whitehall Evening Post unfolded. With a city garrison of only 15 soldiers to protect the Tollbooth, councillors questioned Morice and his associates. They faced a barrage of stones through the windows and demands for the three men's release. At some point the provost emerged to inform the crowd he would order the soldiers to fire if they did not disperse. The response by many present gives a clear indication of how the divisive climate then characterising the city's politics had eroded the sort of respect the leading burgh magistrates could reasonably expect. The crowd - described as 'many thousands' - taunted Cruden, shouting that the soldiers could fire but it would only happen once before they and the Tollbooth were overwhelmed. Unsurprisingly, the arrested men were given back to their supporters while councillors surreptitiously exited the building and sought refuge elsewhere. The extent of hostility towards the incumbent council is underlined by the fact that the provost was followed back to his house, which the crowd threatened to destroy, being dissuaded from doing so in part by the Reverend James Sheriffs, a respected burgh minister. ${ }^{29}$

Aberdeen's civic elite had long projected an image of a well governed burgh. ${ }^{30}$ In the aftermath of the riots this reputation lay in ruins. It says something of the sense of shock and caution induced by these events that the three individuals surrendered back to the crowd were not charged again until early December 1785. The eventual judicial outcome and wider political aftermath were surprising and strongly suggest that many were content to sweep the whole incident under the carpet as quickly as possible, which explains why the riots lack a noticeable historic profile. The incorporated trades could have expected to suffer major recriminations given the central role played by the wrights and coopers and numerous individuals linked to the other crafts. They did not. The crown's officers paid close attention to how the apprentice-journeymen organised themselves, how they initiated new members through a ceremonial ritual of hair washing and, significantly, the taking of secret oaths. ${ }^{31}$ Such concerns would of course emerge strongly during the suppression of Scottish radicalism in the next decade. ${ }^{32}$ Yet at the justiciary court trial in Aberdeen on 15 May 1786 just three individuals were convicted. Only one of the three men initially taken to the Tollbooth was found guilty and just a single wright was condemned. Remarkably, Morice was found not guilty by a majority verdict. The punishments, too, were strikingly lenient: two months

\footnotetext{
${ }^{28}$ NRS, JC26/242, 'Criminal Letters HM's Advocate agst Thomas Morice and others, Aberdeen, Spring 1786', 'Mob and Riot'. 18 Oct. 1785, Provost Cruden and Baillies Black, Paul and Copland. Testimony of Thomas Morice.

${ }^{29}$ NRS, JC26/242, 'Criminal Letters HM's Advocate agst Thomas Morice and others, Aberdeen, Spring 1786', 'Mob and Riot'. 'Aberdeen 6 Dec. 1786: Roger Shand, journeyman wright in Aberdeen compared by Baillie George Adam; '5 Dec. 1785: Alexander Clerk, cutter in Aberdeen, compared by John Copland, Baillie of Aberdeen.'

${ }^{30}$ Skene, A Succinct Survey, 226-228.

${ }^{31}$ NRS, JC26/242, 'Criminal Letters HM's Advocate agst Thomas Morice and others, Aberdeen, Spring 1786', 'Mob and Riot'. Aberdeen, 7 Dec.1786: Compared David Pirie, Journeyman Flesher of Aberdeen.

32 John Stevenson, 'Popular radicalism and popular protest, 1789-1815', in H.T. Dickinson (ed.), Britain and the French Revolution, 1789-1815, (Basingstoke, 1989), 63-63; Harris, The Scottish People, 115-124.
} 
imprisonment and $£ 30$ caution. ${ }^{33}$ This denouement offers an instructive contrast to the usual emphasis on the Scottish judicial system's reputation for heavy-handed and politically motivated repression. Unlike the draconian sentences meted out in the early 1790s, the legal system's sensitivity to local politics in the very different circumstances of the mid-1780s resulted in what amounted to a judicial pouring of oil on troubled waters.

\section{From reform to riot}

How had it come to this? The economic issues shaping the character of the violence between the wrights and the coopers support the analysis that traditional craft and artisanal conceptions of market regulation and occupational demarcation lay at the heart of the matter. The minute books of that trade provide a clear indication of why, during the second day of rioting, a bout of violence occurred at the town's main quay. Earlier in May 1785 there had been complaints that 'unlicensed' men who had not served their time were working on the waterfront as wrights. ${ }^{34}$ This practice was viewed as undermining the established occupational hierarchy and the employment prospects of those aspiring to membership of that trade as full freemen. The grievance explains why journeymen and apprentice wrights moved against the quayside workshop of a prominent local cooper, Alexander Aberdeen, who many clearly believed to be hiring such under-qualified men. ${ }^{35}$ But the records of the various trades show such complaints had been commonplace for years and yet the issue did not normal result in violence. The crucial additional factor at play was the tensions generated by a sustained reformist campaign in the city and the civic language used to forward that objective. The increasingly strident environment in the decade or so before 1785 had a corrosive impact on perceptions of the council's authority and combined with new forms of political rhetoric to alter perceptions of who had a legitimate interest in the city's governance. These trends contributed directly to the events of October 1785 and mean the riots ought to be considered as much a political outburst as a trades-orientated dispute.

The activities of the committee of burgesses, led by two merchants, its president, Patrick Barron of Woodside, and treasurer, John Ewen, are vital in comprehending the civic tensions which shaped the riot's political character. ${ }^{36}$ Under the pseudonym Civis, Ewen authored a number of pamphlets from as early as 1782 which became increasingly critical of the council and repeatedly highlighted the theme of excessive taxation without sufficient representation. ${ }^{37}$ It should be stressed that neither Barron nor Ewen were particularly radical, although a telling indication of where some of the burgesses sat on the political spectrum can be gleaned from the fact that the Aberdeen committee was one of only a handful of associations in Scotland to send congratulations to the French Constituent Assembly in $1790 .^{38}$ In general, however, these men were far less radical than such grand gestures might suggest. They adhered to a reformist ideology that was instinctively conservative in character and framed by ancien regime concepts of legally defined liberties and hierarchical corporate privilege. Such objectives fitted exactly within the established political discourse of stressing the need to combat contemporary forms of constitutional corruption and new forms of

\footnotetext{
${ }^{33}$ NRS, JC11/36: Northern Circuit, May to September 1786: Decimo quinto. Die Mensus, May 1786. David Dalrymple, Lord Hailes and Alexander Murray, Lord Henderland.

${ }^{34} \mathrm{TH}$, Incorporation of the Wrights and Coopers, vol. 13, Minute Book, 1758-1811, 194-5 [27 May 1785].

${ }^{35}$ TH, 'Wrights and Coopers, vol. 13, Minute Book, 1758-1811', 174-75 [6 Aug. 1782]; NRS, JC26/242,

'Criminal Letters HM's Advocate agst Thomas Morice and others, Aberdeen, Spring 1786', 'Mob and Riot'. 18 Oct. 1785, Provost Cruden and Baillies Black, Paul and Copland. Testimony of Thomas Morice.

${ }^{36}$ The Aberdeen Almanack, for the year 1785, 189.

${ }^{37}$ Finlay and Murdoch, 'Revolution to Reform', 278-80; The Aberdeen Journal, 6 Jan. 1783; 28 Dec. 1782:

'Civis to Zeno.'

${ }^{38}$ Harris, The Scottish People and the French Revolution, 83.
} 
arbitrary rule rather than espousing ideas of universal rights and fundamental constitutional change. ${ }^{39}$ Ewen and Barron and the individuals they represented sought the restoration of what were deemed to the 'ancient' liberties of burgesses to hold the council to account at the annual head court and a right to vote on whatever additional tax assessments were levied over and above the statutory obligations due from the burgh. This was a world view where the burgesses acted as 'the honest men of the borough', as the 'true and ancient commons of the kingdom' and where 'the ancient constitution ... [and] local usage' provided the template for how the community ought to be ordered. ${ }^{40}$ Revolutionary it was not. Given these preferences it is hardly surprising that as reformist organisations such as the Scottish Friends of the People adopted increasingly radical objectives from 1793 most burgesses swung towards defence patriotism and general support for the established order.

Yet too much emphasis on the retreat from substantive constitutional change risks prioritising one dimension of the reformers' multifaceted ideology at the expense of other equally important motivations. National, local, conservative, reformist and radical ideas intermingled in highly unpredictable ways. A comprehensive understanding of the unrest in 1785 involves situating the riots in a broader chronology and in a wider awareness of the city's changing political culture during the age of revolution. Contemporaries queried and criticised municipal governance holistically and as part of a framework of individual, propertied, incorporated privileges that tied into a wider conception of Scottish legal precedent and British political rights. The national infused the local and vice versa. Seemingly prosaic debates over water, sewage, street maintenance and lighting - known in contemporary parlance as 'police' matters - were understood in terms of 'constitutional and equitable... taxing of the inhabitants' ${ }^{41}$ Rhetoric imbued with national and even universal connotations was used in ways that imparted greater significance to mundane civic matters and made otherwise abstract ideals about political rights and participation intelligible and relevant. This malleable, constantly shifting use of ideals warns against drawing too stark a difference between concepts of conservative 'reform' and politically progressive 'radicalism'. The traditional, even deferential tone of much of reformist language and tactics did not equate to uncritical acceptance of the status quo. Loyalty to idealised concepts of the national and burgh constitutions could and did easily legitimate dissent and robust criticisms of national government and the burgh magistrates. As is well known this gradual politicization intensified with the outbreak of war against the Americans. The conflict consolidated an anticorruption discourse in English and particularly London-based politics. The extent to which this new critical tone extended to Scotland is a matter of ongoing uncertainty, not least in terms of the extent, intensity, duration and socially inclusive nature of this putative political 'awakening'. ${ }^{42}$ On one side the innately traditional and 'backward' looking aspirations of the county and burgh reformers is stressed alongside their socially exclusive profile. By contrast, the ways in which strident opposition to government proposals over Catholic relief in 1779 encompassed a wide range of groups and generated new trends in political organisation and rhetoric forms a counter interpretation. ${ }^{43}$

\footnotetext{
${ }^{39}$ Ian R. Christie, Wilkes, Wyvill and Reform: The Parliamentary Reform Movement in British Politics, 17601785 (London, 1962), 72-3; Philp, 'The fragmented ideology of reform', p.65.

${ }^{40}$ The Aberdeen Journal, 6 Jan. 1783; 26 Sept. 1785.

${ }^{41} \mathrm{TH}$, Incorporation of the Weavers, vol. 31, Minute Book, 1728-1813 [23 Jan. 1793].

${ }^{42}$ Meikle, Scotland and the French Revolution, 15-16, 33; Harris, The Scottish People, 14-18.

${ }^{43}$ John Dwyer \& Alexander Murdoch 'Paradigms and politics: manners, morals and the rise of Henry Dundas, 1770-1784', in John Dwyer, Roger A. Mason \& Alexander Murdoch (eds.), New Perspectives on the politics and Culture of Early Modern Scotland (Edinburgh, 1982), 214-43; Robert Kent Donovan, No Popery and Radicalism: Opposition to Roman Catholic Relief in Scotland, 1778-1782 (New York, 1987), 214-215; 302-9; Vance, 'Constitutional radicalism', 188-219.
} 
Developments in Aberdeen before and after the riot support the proposition that the 1770s and 1780s marked a substantive gear change in Scottish political culture and expectations in ways that directly shaped trends in the post-1789 period and help explain how respectible 'reform' agenda could quickly transform in popular tumult. The conservative and patriotic tone of local activity in this period can easily mask evidence of a normalisation of active criticism of governments, be they national or municipal. Again and again during the years between 1775 and 1785 the politics of deference and loyalty worked to acclimatise a wide range of interests to critiquing burgh magistrates in Aberdeen and administrations in London. Just how quickly overt patriotism to the established order could turn to pointed censure and alienation is clear from the controversy over how Aberdeen might defend itself from American and Dutch privateers. After a number of cautious lobbying efforts by the council asking for permission to form a militia, a proposal was forwarded in 1781 by John Ewen, later the secretary of the committee of burgesses. Rejection of an earlier proposal by a British government wary of volunteering as a consequence of events in Ireland resulted in Lieutenant-general Alexander MacKay, commander in chief in Scotland, writing to the secretary of state, David Murray, viscount Stormont, noting:

Your lordship must know the natural temper of people of this country, if they see a line drawn, and that they do not share in the confidence of the Crown they will feel it severely - I commanded the Troops at Aberdeen, and on that coast, summer 1778, and in justice to the people, I must be allowed to say, that all Ranks showed the greatest zeal, at the same time I saw they were much hurt with their Association being disapproved of by Government. ${ }^{44}$

The line between loyalty to and disaffection with government could be thin indeed and the dynamic observed by MacKay supports interpretations that stress the less deferential, more combative characteristics of post-union Scottish society. ${ }^{45}$ The records of the incorporated trades reveal increasing disappointment in the burgh's council's unwillingness to reflect wider civic opinion on a number of issues. On 18 July 1775 the deacon convenor's court drafted a memorial rejecting aspects of the council-sponsored parliamentary bill for new taxation and 'police' arrangements. On 12 December 1777 the same body criticised the council's unwillingness to oppose legislation relating to restrictions on food imports, noting that 'it is the general opinion of the inhabitants and trading people in Aberdeen that the intended bill ought to be opposed.' 46 The rhetoric of 'general opinion' and 'the inhabitants' points to the deliberate muddying of who may have had a legitimate if indirect say in the city's political affairs. Here was a 'court' of artisans providing a platform for the expression and normalisation of new political rhetoric and definitions of who constituted the politically involved. The projection of a more ambiguous, potentially open ended conception of who constituted the burgh's politically involved community became a marked feature of reformist campaigning rhetoric. But this political lexicon was not by any means restricted to the 'respectable' citizen burgesses, even as early as the mid-1770s.

Reform interests in Aberdeen never conceived of their efforts purely in local terms and always sought to align with other like-minded groups operating at the Scottish and British levels. In 1783 Patrick Barron, writing to Thomas McGrugar, secretary of the equivalent committee of burgesses in Edinburgh, acknowledged the city's role as the Scottish capital

\footnotetext{
${ }^{44}$ NRS, RH2/4/388: State Papers Scotland, Series 2: S.P. 54, vol. 48, 1780-1783, part I, fos. 62, 105, [quote], fos. 102-103. I am grateful to Dr David J. Brown of the National Records of Scotland for drawing my attention to this material.

${ }^{45}$ Christopher A. Whatley, Scottish Society, 1707-1830: Beyond Jacobitism, towards industrialisation (Manchester, 2000), 158-164.

46 TH, Deacon Convenor Court Book, vol. 2, 1764-1829, 84-85 [18 July 1775], 100-102 [2 Dec. 1777].
} 
while framing their joint efforts as: 'The grievances of which the Burgesses of Scotland complain are those of a very respectable part of the BRITISH PEOPLE to a BRITISH HOUSE OF COMMONS ${ }^{47}$ Although not as fully integrated into a British political vocabulary as would be the case in the 1790s, the Aberdeen reformers of the 1780s deftly balanced ideals of ancient legitimacy imparted by an older Scottish legal framework with a subtle sense of Edinburgh as a natural metropole. ${ }^{48}$ Both cities were also now to be clearly situated within a consciously British framework of more expansive, generic national rights. This is another example of how civic reformist politics of the early 1780s clearly presaged developments usually associated with the era of 1790s.

The reformers' campaign involved the seamless use of centuries-old Scottish legal precedents alongside a British patriotic language of privileges and rights. After a tense head court on 21 September 1784 the committee reiterated earlier requests to view the burgh records all the way back to 1500 in order to establish historical practice and prove that citizen-burgesses had been unconstitutionally excluded from their right to hold councils to account. Requesting the right to see financial records was a tactic common among those seeking to challenge pre-reformed burgh oligarchies. While some councils refused or delayed such access, the Aberdeen magistrates confirmed that individual burgesses had the right to inspect accounts. ${ }^{49}$ The subsequent search, undertaken by Patrick Barron and others, confirmed to the reformers' own satisfaction the importance of legislation passed in 1469 and 1474 and a number of rulings in the 1590s as the 'ancient' basis of Aberdeen's good governance. The information was then used to argue that the Michaelmas head court formed the "constitutional assembly' of the burgh. ${ }^{50}$ Through their use of the burgh records as a legislative archive the reformers knew their history and reconceived the city's past to better service their political present. Scottish legal culture and burgh history played a greater role in reform ideology than might seem the case if attention focuses on the evolution of a national vocabulary of British rights at the expense of local tactics and emphases.

Meanwhile, the council honed its own political discourse. In November 1784, in language that closely foreshadowed the allegations later deployed against radical associations they argued that:

Public meetings of Burgesses have been called and held not only without legal authority but in direct violation of the publick law; ... a Committee has been chosen and officers under the names of President, Secretary and Treasurer have been elected altogether unsanctioned by the constitution and inspire a factious set of burgesses who have presumed to erect themselves into a separate and distinct body and usurp the powers of the legal representatives of the community'. ${ }^{1}$

\section{Burgh authority, community, and the rhetoric of civic reform}

As ideas of who constituted this community became ever more controversial, reformers responded by honing a deliberately expansive and ambivalent political vocabulary. By 26 September 1785 the committee sponsored a petition to parliament for electoral reform

\footnotetext{
${ }^{47}$ Political papers, chiefly respecting the attempt of the county of York, and other considerable districts, Commenced In 1779, And Continued During Several Subsequent Years, to effect a reformation of the Parliament of Great-Britain: collected by the Rev. Christopher Wyvill, Chairman of the late Committee of Association of the County of York. vols. I-VI (York, 1794-1802), iii, 19.

${ }^{48}$ Pentland, 'Patriotism, universalism', 344.

49 ACAA, C1/1/65, fos. 68 \& 111.

${ }^{50}$ Meikle, Scotland and the French Revolution, 19-21; Further Proceedings, 23; ACAA, C1/1/65, fos. 65-67.

${ }^{51}$ ACAA, C1/1/65, fos. 70-72.
} 
which called for signatures from 'burgesses, freeholders, traders, manufacturers and other inhabitants of Aberdeen'. A copy was made available at Alexander Cheyne's shop on the Narrow Wynd for ease of subscription. Broadening the basis of participation in civic politics - as distinct from seeking greater national electoral enfranchisement - formed a central part of this tactical response. ${ }^{52}$ A long list of memorials submitted to the tax assessors from January 1785 onwards moved away from an exclusive reliance on the privileged language of 'burgess' and 'citizen' to note that all local police funds were 'by authority of the inhabitants themselves'. ${ }^{53}$ On the eve of the bitterly divisive Michaelmas head court of 27 September 1785 which set the immediate context for the riots, the committee of burgesses held a general meeting at the concert hall on Queen Street. The resolutions approved by 215 burgesses were dismissed by the council the next day as 'really very unconstitutional and wrong'. ${ }^{54}$ John Ewen responded that the proposals had the support 'not only of the trades convenor and deacons... but the greater part of the whole body of the incorporated trades, with a majority of the guildry and many of the inhabitants. ${ }^{55}$ Both sides noted the populist character of the head court meeting, believed by many to be the most crowded in living memory. The Tollbooth stairwell and lobby had been packed 'with other inhabitants', not simply citizen burgesses. In that context Patrick Barron claimed 'that popular assemblies are not, by any means, such dangerous things', a defence of populist politics which, despite the riot three weeks later, Ewen was willing to defend again in another pamphlet in 1786. Despite events in his home city he argued strongly against the portrayal of reform as a step to rule by the mob. By this stage the language used had evolved well beyond the lexicon of corporate privilege, with Ewen concluding that the Aberdeen committee's campaign 'afford[s] pleasure to every friend to the liberties of mankind'. ${ }^{56}$ As the reformers sought to legitimate their aims in the face of the council's opposition their conceptions of political participation shifted incrementally towards populism and even tentative shades of the language of univeralism. Such terminology would not have look out of place in the early 1790 s.

The new, more inclusive political tone heightened expectations and sharpened divisions, nowhere more clearly than in the city's incorporated trades. The weavers, the tailors and the wrights and coopers trades evinced a clear and persistent interest in local and national affairs. In November 1782 the wrights and coopers complained of the council's inequitable methods for quartering soldiers. But criticism was always consciously balanced with expressions of deference and support. In February 1784 the deacon convenor's court issued proclamations of loyalty to the established constitution, the defence of monarchical privilege and the corporate rights of the East India Company. ${ }^{57}$ This defence of a similarly ancien regime corporate body may appear conventional, but these activities also accustomed the trades to debate and even overly criticise national governments. In other words, even the politics of loyalty politicised elements of the population excluded from formal enfranchisement. The legacies of this politicisation proved to be highly unpredictable and would ultimately generate new divisions between and within the town's established civic interests in ways that contributed directly to the riots.

A key tactic of the committee of burgesses involved allying with the seven incorporated trades, whose apprentices and journeymen would go on to spark the riot.

\footnotetext{
${ }^{52}$ Aberdeen Journal, 26 Sept. 1785.

${ }^{53}$ Aberdeen Journal, 26 Sept. 1785; Further Proceedings, pp. 9-10, 33.

${ }^{54}$ The Aberdeen Journal, 3 Oct. 1785

55 The Aberdeen Journal, 26 Sept. 1785.

${ }^{56}$ Further Proceedings, 33-38; Observations, By Civis of Aberdeen on a letter under the signature of A Cobler (Aberdeen, 1786), 17-18, 21.

${ }^{57}$ TH, The Deacon Convenor Court Book, vol. 2, 1764-1829, 136-138 [5 \& 25 Mar. 1784]; Trinity Hall,

'Wrights and Coopers, vol. 13, Minute Book, 1758-1811', 185 [14 Feb. 1784].
} 
Courting of the artisanal orders by burgesses as a means of generating a broader populist sentiment against burgh councils was neither a new tactic nor unique to Aberdeen. In 1777 competing interests in Edinburgh had sought to marshal the influence of the city's incorporated trades. ${ }^{58}$ The difference in Aberdeen was the duration and depth of the cooperation, spanning as it did over twenty years, although activity tended to peak and trough in phases. The committee welcomed formal delegates from the trades to all its meetings. Those involved often held or aspired to prominent office in their respective crafts and included William Bain, a weaver, who was appointed as a delegate on 2 March 1784. The wrights and coopers' delegate was William Still, who a year later attempted to quell the disorder, while John Low represented the tailors. ${ }^{59}$ These nomination, election, and delegating arrangements mirrored the wider Scottish reform movement's method of organising conventions of burgesses and trades representatives in Edinburgh to draft proposals for an alteration of the burghs' civic and parliamentary franchise. The simultaneously adoption of such practices in Scotland's primary northern metropole indicates how political trends and innovations moved rapidly across the country in ways that clearly pre-dated the better known quickening of politics in the early to mid-1790s.

Meanwhile, the reform bill drafted in Edinburgh intended to retain the existing number of trades' deacons in all Scottish burgh councils but by direct election rather than through indirect nomination by the incumbent magistrates. It is a measure of how expectations were rapidly evolving among urban trades and artisanal groups that even this proposed change did not go remotely far enough. The records of the Aberdeen tailors and weavers underline the extent to which the previous ten years had induced greater levels of political awareness and engagement. As early as 15 March 1784, the tailors unanimously approved a far more ambitious objective: 'The Trade having fully deliberated upon said subject they are unanimously of opinion that the number in Council of the Incorporation should not be under one third part, which they consider themselves entitled to from the sums paid into the Town'. The weavers had already approved this idea on 2 March. ${ }^{60}$ This innovation would have tripled the trades' representation on the city's council and demonstrates that artisan interests did not slavishly adopt the preferences and priorities of the burgesses. They carved out their own political aspirations, and even while in alliance with reform-minded burgesses were still noticeably independent. The assertiveness of craftsmen and artisans in the Friends of the People conventions of 1793 finds a striking precedent in the attitudes of some of Aberdeen's incorporated trades nearly a decade earlier.

At work was a conception of civic politics that resonated clearly with recent events in America but which worked from a different starting point. Many of the local taxes or 'stents' raised in Aberdeen and the other Scottish burghs were legitimated among those that paid them by having existed for decades, if not longer, and raised in a manner broadly accepted by the relevant sections of the populace. Taxes already existed and were never in doubt; what animated the Aberdeen burgesses and trades was the objective of securing proportional representation for taxation. Here is an example of local priorities reshaping the principles espoused during the revolution in North America. Rather than 'no taxation without representation', the emphasis was reversed and focused on acquiring electoral representation to ensure executive accountability. In practical terms this concern revolved around practical

\footnotetext{
${ }^{58}$ Harris, The Scottish People, 22-23.

${ }^{59} \mathrm{TH}$, Incorporation of the Weavers, vol. 31, Minute Book, 1728-1813 [2 Mar. 1784]; TH, 'Wrights and Coopers, vol. 13, Minute Book, 1758-1811', 186 [5 Mar. 1784]; TH, ‘The Taylior Traide of Aberdeen', vol. 5, Minute Book 1694-1794, No. 31, fos. 301-2 [15 Mar. 1784].

${ }^{60}$ TH, 'The Taylior Traide of Aberdeen', vol. 5, Minute Book 1694-1794, No. 31, fos. 301-2 [15 Mar. 1784]; Incorporation of the Weavers, vol. 31, Minute Book, 1728-1813 [11 Mar. 1784].
} 
'police' matters and the taxes required for routine maintenance of the city's infrastructure. ${ }^{61}$ Between 1775 and 1795 the committee of burgesses and the incorporated trades objected to council police plans on no less than ten separate occasions, with the longest hiatus between protests never more than three years. ${ }^{62}$ The campaign against the council on police matters was persistent enough to ultimate shape aspects of the legislation finally passed by parliament in 1795. It is for this reason that the committee of burgesses is viewed as one of the most successful of the reform associations. At a time when many reform-inclined whigs had been hounded from national political life, reformist burgesses such as Patrick Barron, John Ewen and associates like Alexander Cheyne made up no less than $20 \%$ of the elected police commissioners. In some strictly limited ways, the Aberdeen reformers obtained a part of what they wanted, although the gains were later negated by further council manipulation of the city's financial development. ${ }^{63}$

\section{The politicization of the Trades}

However, the compromise of the 1795 Police Act lay in the future. In the 1780s the political climate was characterised by ever closer co-operation between the trades and the committee of burgesses and a growing willingness to be actively critical of the council. Tension and divisions was inevitable. In the case of the trades, a key source of turmoil was the contentious question of whether fees and funds raised from among its members and its apprentices and journeymen should be put to political uses. The tailors had no doubt on this score, and neither did the weavers. From March 1784 onwards both incorporations authorised spending from their common fund for delegates to attend both the committee of burgesses meetings and the national convention in Edinburgh. The weavers' commitment to the reform agenda ensured the unanimous approval on 28 April of a motion that 'the trade are of opinion that the business of reform should be persevered in with steadiness'. ${ }^{64}$ The tailor's society initially proposed that individual members contribute to expenses according to conscience, but on 9 April moved approved the use of common funds for political expenditure. The wrights and coopers, by contrast, were far more tentative and conservative, refusing to allocate any money, preferring instead to allow members to subscribe individually. ${ }^{65}$ In April 1785, as these debates over spending intensified, the wrights and coopers court authorised an increase in apprentice fees, ostensibly for allocations to local good causes. Who controlled this augmented income, and to which purposes it would be deployed, became a defining point of tension within the organisation. The wrights and coopers' boxmaster was none other than William Still, one of the delegates to the burgesses' reform committee; on 17 October, the day of the first phase of rioting, he was appointed full deacon. Meanwhile, the outgoing deacon, John Lamb, from whose house Thomas Morice and the other wrights acquired the flag on the second day of rioting, clearly held influence with the council. Despite the conspicuous involvement of journeymen and apprentices from his trade, Lamb was elected by

\footnotetext{
${ }^{61}$ Rosemary Tyzack, "No mean city'? The growth of civic consciousness in Aberdeen with particular reference to the work of the police commissioners', in Terry Brotherstone and Donald J. Withrington (eds), The City and its Worlds: Aspects of Aberdeen's History since 1794 (Glasgow, 1996), 150-152.

${ }^{62}$ Further Proceedings of the Burgesses, iii-x, 5-59; TH, Incorporation of the Weavers, vol. 31, Minute Book, 1728-1813 [25 May 1791, 23 Jan. 1793, 19 Feb. 1794].

${ }^{63}$ The Aberdeen Almanack, for the year 1796 (Aberdeen, 1796), 177; Tyzack, 'No mean city’?', 152-153; Finlay and Murdoch, 'Revolution to reform', 284-285.

64 TH, The Taylior Traide of Aberdeen, vol. 5, 'Minute Book 1694-1794, No. 31', fo. 302 [6 Apr. 1784]; TH, Incorporation of the Weavers, vol. 31, Minute Book, 1728-1813 [19 Mar. 1784, 28 Apr. 1784]; 25 May 1791, 23 Jan. 1793, 19 Feb. 1794].

65 TH, 'The Taylior Traide of Aberdeen, vol. 5, 'Minute Book 1694-1794, No. 31', fo. 302 [6 Apr. 1784];

'Wrights and Coopers, vol. 13, Minute Book, 1758-1811', 186 [14 Feb. 1784].
} 
the magistrates for year 1785 and 1786 as one of the two trades' councillors. A telling indication of his political sympathies can be found in the fact that, only four days after the riot partially induced by his fellow wrights, he was appointed to the politically sensitive post of stent assessor ${ }^{66}$ Co-relating the trades and council records reveal that the leadership of the wrights and coopers was split right down the middle; the wrights being predisposed to a less politically motivated use of funds and, in the person of Lamb, retaining active involvement in the council. The coopers, by contrast, aligned far more clearly with reform, and in the person of the newly elected deacon, William Still, seemed on the cusp of taking control of the wrights and coopers. To compound the fears of those concerned at the politicisation of the city's artisan classes, the same day another prominent trades delegate to the burgesses, the tailor, John Low, was elected as deacon convenor of the seven incorporated trades. The election of these men facilitated rumours that funds would pass under the control of reformers and be used to support the work of the committee of burgesses. Such indeed was Low's reputation in this regard that he later faced accusations he had endeavoured to use the seven incorporated trades' finances to assist alleged rioters. ${ }^{67}$

The divisive climate sparked fears among journeymen and apprentice wrights over the potential use of monies raised from them in fees and led ultimately to an internal conflict with the coopers which then spiralled out of control into a more generalised riot. What began as an essentially 'conservative' demonstration by wrights against the potential for a political hijacking of their own financial and political resources ended up with the council the target of mass protest. Under these circumstances, with both conservative and reformist sympathies in play, it is hardly surprising that both sides chose to move on as quickly as possible. Understanding the background to the riot itself is to appreciate how the idea of reform unleashed a set of widely different expectations, tensions and contradictions between the different trades and, in the case of the wrights and coopers, even within an individual trade. The nascent alliance between the reformist burgesses and the trades was unstable and induced discord that ultimately spilled into internecine assembly and general mobbing. One of the significant lessons which events in Aberdeen offer for an wider assessment of Scottish political culture in this period is that they reveal the severe difficulties of securing a stable dynamic between 'respectable' reformers and artisanal, trades organisations.

\section{Conclusion}

A review of the events in mid-October 1785 also underscores the value of combining Aberdeen's various civic records with those of the central judicial authorities. The council registers and the minute books of the various trades simply do not deal with the matter. The riot is never mentioned. Too many of the leading players in both organisations were either humiliated, implicated or compromised by the string of events and politicking which contributed directly and indirectly to the events of 17 and 18 October. This underscores the need to realise the limitations and the eloquent silences that pervade what are undoubtedly an unusually complete set of Scottish city records. Yet if used in conjunction with judicial proceedings, the city's unusually dense web of associated civic archives mean it is possible to piece together in detail the underlying causes and oddly subdued aftermath of one of postunion Scotland's most serious political riots.

There are lessons too for how Aberdeen evolved as a political and civic entity and of the value of remaining sensitive to local and regional developments when attempting to

\footnotetext{
${ }^{66} \mathrm{TH}$, 'Wrights and Coopers, vol. 13, Minute Book, 1758-1811', 186 [14 Feb. 1784]; 198-199 [17 Oct. 1785]; Aberdeen Almanack, for the year 1785, 60; Aberdeen Almanack for the year 1786, 177.

${ }^{67}$ Warren, Speculum ruris, 43-44; Letters to the Citizens of Aberdeen, 36-37; The Aberdeen Journal, 7 Nov. 1785.
} 
understand broad phenomena such as 'reform' or 'radicalism'. A clearer picture can be gleaned of how the city functioned as an early modern provincial metropolis and the ways in which it evolved a whole set of links to the rest of Scotland and Britain. A marked feature of Aberdeen in the 1780s and early 1790s was the vibrancy of its political culture and the utilisation of national and even international ideas for local civic purposes. Men like Patrick Barron and John Ewen were major figures in the Scottish reform movement and their activism from the mid-1770s to mid-1790s point to crucial continuities in personnel across the watersheds of the American and French revolutions. As if mirroring Ewen's own claim that Aberdeen held 'rank as the third town in Scotland', contemporary commentators recognised the city's leading role in pursuing an improved burgh politics which would match its role as the commercial centre of the north. ${ }^{68}$ In this way new ideas of political reform, just as surely as older, legalist inflected concepts of the burgh's ancient character, were now used to confirm its status as a provincial metropole in the Scottish and increasingly British urban hierarchy.

And lastly, the case of the Aberdeen riot, and the intense civic politicking that surrounded it, point to the ways in which it is possible to address the enduring question of the continuities and changes shaping Scottish and British politics in the age of revolution. Local reform proved in some ways to be a more robust, flexible and responsive phenomena when compared to the relatively quick marginalisation of constitutional issues in the early to mid1790s. Indeed a review of the city's dynamic civic political culture also leaves the 1780s and 1790s looking much more similar in a number of key respects, be it in terms of political mechanisms such as petitions and general meetings, or emergent political confluences between privileged burgess interests and trade-artisanal groupings. The Aberdeen committee of burgesses' ideas and rhetoric strongly suggests that the impact of the American War on Scotland may well have been more substantial and sustained than is sometimes supposed. Reform-minded groups in the city undoubtedly sought to broaden their political methods, both by reaching out to the incorporated trades and by adopting a subtle, capacious vocabulary designed to win a wider legitimacy beyond their own immediate constituencies. But, as was to be the case again in the 1790 s, such alliances were highly unpredictable, moving rapidly beyond the control of citizen-burgesses as trades deacons struggled in turn to regulate the aspirations and the fears of their journeymen and apprentices engendered by the change in political tone and language. The dramatic events in Aberdeen in October 1785 were not, as the Whitehall Evening Press would have it, the meeting of older Jacobite and Republican traditions. But even while mislabelling the city's politics, the paper may well have had a point. The innovative, rapidly evolving and unstable political and civic experimentation that characterised 1780s Aberdeen constitutes a significant and an underappreciated glimpse into the new forms of politics emerging all over Scotland and the rest of the British-Irish Isles.

${ }^{68}$ Observations, By Civis of Aberdeen, 9; Graham, A Letter to the Right Honourable William Pitt, 46. 